\title{
Interrogating Absence: The Lawyer in Science Fiction
}

\section{Abstract}

This article argues that whilst concepts of law and justice can be seen as prominent in much science fiction, the role of lawyer is mostly absent. This article interrogates these absences and asks whether they can be traced back to contemporary concerns around professional ethics. Three potential absences are noted; firstly, justice is considered as immanent. In these fictional futures lawyers have become unnecessary due to the immediacy of the legal system. The second conceptualisation portrays lawyers as intertwined with corporate interests. In these speculative moments lawyers have become culturally indistinguishable from other types of corporate entities. The final science fictive texts highlight a desire for the lawyer-hero. In these texts justice is overwhelmingly absent and shows a continuing need for legal professionals. Each of these cultural moments present important questions for current understandings of professional ethics and the regulatory systems in which they are based. A removal of lawyers from our shared understandings of the future is indicative of potential problems with perceptions of professional ethics in the present.

\section{Introduction}

Science fiction has dealt with a proliferation of different legal themes; covering and critiquing topics as wide as legal personhood (Blade Runner, Scott, 1982, Species, Donaldson, 1995, Natali, Splice, 2009), environmental law (Akira, Otomo, 1988, 2012, 
Emmerich, 2009, The Day After Tomorrow, Emmerich, 2004) and the nature of justice (Judge Dredd, Cannon, 1995, Minority Report, Spielberg, 2002). The importance of science fiction to law has been noted previously in relation to justice, the judiciary and technology (Travis, 2011, Tranter, 2011). The rich imaginary terrain offered by science fiction allows it to cover almost any legal issue and it is this use of the imagination that helps us to consider new approaches to - and directions in - law (Aristodemou, 2000, Sherwin, 2000). For example, even the lacklustre and critically condemned fifth film of the Star Wars franchise Attack of the Clones (Lucas, 2002) provided in its representations of a decayed Republic tipping into authoritarian Empire through civil war, material for legal scholars to use to illuminate contemporary concerns with the exception and responses to terror (Peters, 2012). Similarly, the legalities of Isaac Asimov's 'Three Laws of Robotics' from his robot short stories (Asimov, 1950/2008; Asimov, 1964/1967) and novels (Asimov 1954/1983, Asimov, 1957/1960, Asimov 1976, Asimov 1985) have been used as a sophisticated commentary on the complexities of literal and purposive interpretation (Leslie-McCarthy, 2007).

Given the propensity of science fiction to present issues of law and justice there appear a notable absence - the figure of the lawyer. This article questions this absence of the lawyer from our often law-ful (that is full of law) fictional futures.

This paper is structured according to three interrogations of the absence of lawyers in science fiction. The first is that law and justice is represented as imminent; that law and justice will be manifest in the future without the need for lawyers. The second is that law and justice become corporatised; transformed into commodities that are owned and traded by an imagined hyper-capitalism. The third is that the telling absence of lawyers and projecting a need for the lawyer-hero in the future. 


\section{The Absence of the Lawyer in Science Fiction}

Questions of law, legality and justice are often at the forefront of science fiction texts. From Asimov's Laws of Robotics to the Star Trek franchise's Prime Directive law is a regular feature of science fiction (Peters, 2008; Rockwood, 1999, pp. 274-275; Joseph and Carton 1992). Many science fictions have dealt with the legality of specific technological changes, from cloning (see the texts discussed by (Corcos, Corcos et al., 1999), artificial life (such as Bicentennial Man (Asimov, 1976) and (Columbus, 1999), genetic discrimination Gattaca (Niccol, 1997) and time travel Looper (Johnson, 2012). Further, there seems a particular focuses on the future of law, order and policing within science fiction. The iconic Blade Runner (Scott, 1982) is in essence a cops and robbers story of policing androids and the not so iconic Minority Report (Spielberg, 2002) concerns predictive policing and police force integrity.

However, as Paul R Joseph noted in the context of science fiction television, while science fiction does law, it does not provide many lawyers (Joseph, 1998). Other professions are highly represented within science fiction. Military personal, doctors, scientists, engineers/inventors, politicians, corporate executives and police regularly people science fiction's representation of the future (Schedle, 1993, pp. 27-37). Joseph further suggests that when lawyers do make a rare appearance in science fiction it is usually in a familiar and conventional courtroom setting where the lawyer is shown as "Perry Mason in space"; a photocopy of the common within popular culture representation of a lawyer as a zealous oral advocate defending or prosecuting in a criminal matter (Joseph \& Carton, 1995, p. 306). Joseph's thesis is defensible. More recent support for Joseph’s claim concerning the limited imagining of lawyers in science fiction can be found in the animated series Futurama (19992013) which has a minor reoccurring lawyer character - Hyper Chicken (voiced by Maurice 
LaMarche) - whose urban Southern accent and mannerisms parody that pinup of twentieth century lawyer in popular culture, Atticus Finch. ${ }^{\mathrm{i}}$

For Joseph the limited imagining of lawyers in science fiction shows a fault with the creators of science fiction. He urges science fiction to extend its speculation and imagining to law to provide “a more inventive portrayal of lawyers” (Joseph \& Carton, 1995, p. 311) and that "there is nothing intrinsic to science fiction which would preclude the inclusion of legal issues and characters” (Joseph, 1998, p. 158). While Joseph does identify some more inventive portrayal of lawyers within science fiction, our aim is not to critique science fiction. Indeed, we suggest that the absence of lawyers from science fiction reveals a popular wisdom about lawyering when considered in the context of the future. The absence of lawyers from science fiction is not so much a criticism of science fiction but actually is a criticism of contemporary lawyering. It shows a speculation on the future where there are doctors, police, military officers, scientists, but not lawyers. It suggests a finality - a doom to lawyers in the popular imaginings of the future which seems incongruous when lawyers appear to be such an important part of the contemporary West and a highly visible profession within other popular culture genres (Robson \& Silbey, 2012). Lawyers have not been written out of science fiction due to their current non-proliferation. There must, consequently, be deeper, cultural reasons for their lack of representation in science fiction.

We suggest that there are three ways in which law and justice has been represented within science fiction that has contributed to the absence of lawyers. Two transmit highly critical and negative accounts of contemporary lawyers. The third is more rehabilitatory, if perhaps reactionary, in that it projects the desire for the lawyer-hero. The first way is that lawyers are seen as superfluous at best, or downright corrosive at worse, to law and justice 
reflecting the regularly identified negative turn in the public's opinion and confidence in the legal profession. The second is that the lawyers are seen to have lost their unique professional identity to become regarded as just another agent of corporate capitalism; a shift that is also reflected in contemporary changes to the legal profession. The third way is embedded in the representations of injustice with science fiction as creating a desire for lawyers to challenge oppressive regimes.

\section{Law and Justice as Immanent}

The recent film Dredd (Travis, 2012) is set in the not so distant future and draws upon the successful British 2000AD comic book character. The film focuses on the character Judge Dredd.. In this alternate future there is no separation of powers. Justice, in this world is handed out in an immediate fashion. If an individual is seen to be breaking the law the trial will be affected at the time of arrest. Justice is immanent and the need for lawyers is removed. The lack of opportunities for lawyers is reinforced by the inability to appeal against sentencing. This film is interesting, as recognisable parts of the legal system still exist: judge, trial and police are named and identified. The absence of the lawyer is amplified, to some extent, through the audience's familiarity with these structures. The absence of lawyers, in Dredd, is necessitated by the immediate implementation of justice.

In part, the lack of lawyers in Dredd evidences of a belief that the legal system is infallible. In Dredd lawyers are rendered superfluous by a form of justice that is immediate and mechanistic. The armoured, machine gun toting Dredd bestride his 'lawmaker' motorcycle is a similar vision of a technological enhanced cyborg justice (Parker, 1998, 504) as other comic book heroes such as Batman or Ironman. Dredd's difference is that unlike the 
Dark Knight and his problematic relations with the Gotham City police force (Sharp, 2012), Dredd is the legal system. In the Dredd backstory the judges were manufactured (through a combination of recruitment and later cloning) in order to be incorruptible. When Judge Dredd claims that he is the law, he believes it. He is the manifestation of embodied justice, trained in the art of both combat and law.

Dredd projects twin fantasies concerning the future of the legal system. The first is that the contemporary legal system of rights, lawyers and processes is inadequate to deal with the challenges of escalating violence and crime. The second is that a more automated system of technology and immediate decision would be more successful. It immediately contradicts this premise. Dredd's Mega-City One is clearly dystopian, for notwithstanding the presence of the judges lawlessness, crime, illicit drugs and corruption remain widespread. As witnessed in the body count of innocents in Dredd, Dredd's technology and decision does not seem to make his world safer.

Nevertheless Dredd in envisaging a legal system that has no roles for lawyers points to a particularly negative set of popular conceptions about the legal profession. Lawyers are a symptom of a dark essence of humanity; needed in a world populated by creatures that seem to have an inability to get along and act civilly to each other. This can help explain the rarity of lawyers in more utopian visions of the future. Lawyers are arguably underrepresented in the Star Trek franchise because the society depicted has moved beyond the division, distrust and violence of humanity's lawyer filled past. In these science fictions a more enlightened humanity has dispensed with the need for lawyers, like earlier generations had with blacksmiths. However, this association of lawyers with a dark humanity takes on a stronger 
emphasis in many science fictions. Lawyers are not just seen as a symptom but active agents in violence, greed and corruption.

In the wider Judge Dredd canon, lawyers are not unknown. In the early comic "The Face Change Crimes” Dredd uses face changing technology to impersonate a defence lawyer to gather evidence against three suspected bank robbers (Wagner, 1978). The lawyer is shown as not just a symptom of an imperfect justice that has to deal with a brutish humanity but as an active participant in the prevention of justice. This association is made even stronger in the short-lived SyFy television series Caprica (2010). Caprica was highly unusual in that it provided in the character of Joseph Adama (Esai Morales) a lawyer in a lead role. Adama is not a good lawyer. Implicated and indebted to organised crime, Adama's 'law work' appears to consist of delivering threats, bribing officials and sleeping with his associate (Tranter forthcoming). He is not shown in court as the zealous advocate rather he skulks around corporate offices as the less than noble suited henchman for criminals.

This vision of lawyers within science fiction has popular resonance. As Andy Boon and Jennifer Levin highlight in the UK:

A popular view of lawyers is that they are amoral technicians; skilful manipulators of legal rules in their clients' legal interests, who, by definition, suppress their own moral convictions. This vision of the lawyer has been described as "pure legal advocacy," a model which discourages behaviour conducive to the attainment of virtues such as truth, honesty and justice. (Boon \& Levin, 1999, p. 32)

It is this cultural mistrust of the profession that is being manifest in science fiction's negative portrayal of lawyers. In Star Trek lawyers are seemingly unnecessary in a more enlightened society and in worlds of Dredd and Caprica lawyers appear as barriers to justice (Boon \& Levin, 1999, p. 34). 
These cultural suspicions seem to endure despite regulative bodies attempts to project the image of the legal profession as facilitative of justice. The first of the ten principles of the Solicitors Regulation Authority Code of Conduct 2011 for England and Wales advises solicitors to "uphold the rule of law and the proper administration of justice.” Similarly, part 301 of the Fundamental Principles of The Code of Conduct for Barristers in England and Wales advises that barristers must not:

(a) engage in conduct whether in pursuit of his profession or otherwise which is:

(i) dishonest or otherwise discreditable to a barrister;

(ii) prejudicial to the administration of justice; or

(iii) likely to diminish public confidence in the legal profession or the administration of justice or otherwise bring the legal profession into disrepute.

The preamble of the Model Rules of Professional Conduct for the American Bar Association similarly note that "[1] A lawyer, as a member of the legal profession, is a representative of clients, an officer of the legal system and a public citizen having special responsibility for the quality of justice.”

Notwithstanding these statements, the public seems quite committed to the vision of lawyers as untrustworthy of the legal profession. Michael Asimow points towards the results of a Harris Poll in 1997 measuring public confidence in institutions (Asimow, 2001, p. 1340). The poll found that legal services “...registered the lowest rating of any institution about which the Harris Poll had ever inquired” (Asimow, 2001, p. 1340). More recently, Gallup Polls have revealed that $38 \%$ of Americans would rate the ethical standards of lawyers as very low; marginally beaten by insurance salespersons, Members of Congress and car salespeople. ${ }^{\text {ii }}$ In the UK these statistics are echoed; a recent survey showed that only $45 \%$ of 
those surveyed would trust lawyers. ${ }^{\text {iii }}$ In Australia the annual "Image of the Profession Surveys” had in 2013 only 36\% of respondent rate lawyers as high for ethics and honesty. ${ }^{\text {iv }}$ While science fiction is not responsible for the social mistrust of the legal profession identified in the surveys, what we are suggesting is a mutually reinforcing process of negative popular opinion about lawyers fuelling and in turn being fuelled by negative popular culture representations of lawyers.

A significant dimension to this reinforcing process between science fictional representations of lawyers and popular opinion is the depictions of lawyers as leading opulent lifestyles with access to enormous wealth. ${ }^{\mathrm{v}}$ The Dredd universe in providing speculation of an immanent system of law and justice does so through disconnecting the legal system from money. The Judges in Mega-City One are not paid and the representations of the limited domestic life of the Judges draw more upon monastical traditions than the materialism of modernity. This desire in Dredd can be seen as a reflection on public dissatisfaction with the cost of law and the perceived greed of the legal profession. There is some substance behind this dissatisfaction. Some large firms such as Clifford Chance have earned upwards of \$1.9 billion in gross revenue (Sechooler, 2008, p. 231) and in a 2012 survey UK lawyers were found to be earning just under three times the national average income. ${ }^{\mathrm{vi}}$ Similar figures concerning rising average salaries for lawyers and the profitability of law firms has been reflected in the American system. ${ }^{\text {vii }}$

The money that lawyers earn seems to conflict with their roles as custodians of justice. Part of the reason that lawyers have been culturally portrayed as villainous is due to a societal distaste for the intertwinement of justice and money. ${ }^{\text {vii }}$ This has been compounded in 
the UK by recent changes to legal aid. The Legal Aid, Sentencing and Punishment of Offenders Act 2012 came into force in April 2013 and removed access to state funded legal services from a large range of previously funded areas of legal practice.. Law Society president John Wotton warned that:

The consequence of this act will be that, in some very important areas like housing and welfare benefits law, vulnerable members of society will find legal advice and representation in the courts, funded by legal aid, more difficult to obtain. ${ }^{\text {ix }}$

Although the motivation for these changes to legal aid came from the Government's budgetary position rather than the legal profession, it nourishes a perception of lawyers as working in the interests of self-gain rather than justice. Moreover, it suggests that lawyers are barriers to, rather than facilitators of, justice. As a consequence, it is easy to understand why some science fictions would try to imagine a world in which lawyers did not exist. A legal system in which, although imperfect, justice is both immanent and free.

\section{Law and Justice as Corporate}

Science fiction also suggests other ways in which lawyers have become absent, by being subsumed into corporate capitalism. Although interrelated to the identification of lawyers as villainous and self-serving, a further trope within science fictions is a legal systemwhere "justice" is bought and traded by corporate interests. Science fictions that involve this narrative tend to project a dystopian future. Three well known examples where this narrative of law and justice is present are Margaret Atwood's Oryx and Crake (2004), William Gibson's cyberpunk pioneering Neuromancer (1984) and Kim Stanley Robinson softlydystopian Gold Coast (1988/1995). 
In these worlds corporate structures have subsumed or become more powerful than governments. In Oryx and Crake the police force (known as the CorpSeCorps) is financed entirely by corporations. The agenda of this privatised police force, as a result, is set entirely by corporate interests including the protection of corporate intellectual property and the silencing of oppositional voices. It is not that corporations are above the law rather they have become the law. In the sprawling violence and inequality of Neuromancer lawyers and law firms are alluded to but not introduced as characters (Effross, 1997, p. 970). They are mentioned in-text as elite resources utilised by the large companies beyond the financial reach of the ordinary citizen. Lawyers are absent in the corporate machinations and excesses of the world told in reminiscences by the protagonist in Oryx and Crake. However, their presence could be assumed by the large amounts of intellectual property that the corporations fight over within the text (Sanderson, 2013, p. 236). Within these worlds of hyper-capitalism the law has become a commodity to be stockpiled and utilised by corporations. With this commodification of law, lawyers lose their professional identify and become subsumed into the corporate structure (Effross, 1997, p. 946-9).

This subsuming into the corporate structure can be seen in the character of a lawyer Louis Goldman in Gold Coast. The novel portrays parallel justice systems. There is the lawyer-free regime of police/corporate security that the protagonist and his drug dealing/political saboteurs associates interact with in near-future California, whereas Goldman in Washington uses litigation and contacts to further his corporate clients interests (Stanley Robinson, 1988/1995). While less radically dystopianGold Coast with it lawyer-less street justice and lawyer-full corporate justice, highlights how lawyers have become absent within science fiction through merging with the corporation. In seeing the corporatisation of 
law, these science fictions can be seen reflecting and amplifying popular anxieties concerning the future of the legal profession.

Concerning the changing image of the big law firm in popular culture Asimow writes:

... judging from contemporary films, big law firms are among the most evil entities to be found in America. This is not so surprising, given that the public appears to loathe both lawyers in general and law firms in particular. Moreover, big law firms are themselves a big business and they champion the cause of big business. This insures that law firms will prove to be handy narrative antagonists. It also guarantees that the general public will continue to be taught, and will continue to believe, that law firms are the embodiment of evil. (Asimow, 2001, p. 1391-2)

During the second half of the twentieth century there was a shift in legal practice away from sole practice towards increasingly large corporate legal firms (Galanter \& Roberts, 2008, Asimow, 2001, p. 1366). In the UK s large law firms moved to recruitment practices based on “certified educational merit” (Galanter \& Roberts, 2008, p. 154) this meant that there was an “emphasizing advice over oratory and encouraging lawyers to be primarily business advisors instead of courtroom advocates” (Beard, 2010, p. 971). These shifts led to profit making becoming the ultimate objective of lawyers rather than "expert knowledge, standards, selfregulation, higher calling, public interest and common interest across the whole profession....” (Francis, 2004, p. 343) As a result legal services have become products sold in accordance with the free market (Nicolson \& Webb, 1999, p. 284). This raises problems with the profession's claims to self-regulation and obligations to justice. If the profession's ethical compass has shifted to one dominated by profit then its claims to self-regulation are diminished.

This difference in practice has been mapped out in popular culture. Since the 1970's Asimow notes that portrayals of good lawyers are few and far between. Moreover, lawyers 
who are portrayed in this manner are likely to be sole practitioners fighting against large, corporate law firms (Asimow, 2001, p. 1349). Consequently, we can trace a perceptible difference in the representation of lawyers in film from Atticus Finch in To Kill a Mockingbird (Mulligan, 1962) to Kevin Lomax in The Devil’s Advocate (Hackford, 1997). Lomax’s ties to the large legal firm leave him, literally, fighting to save his soul.

Science fiction takes these concerns with the rising dominance of the business of law and places it in within wider concerns concerning transnational capital and the corporate form. In seeing lawyers subsumed into the corporation Oryx and Crake, Neuromancer and Gold Coast project lawyers as just another profession hired to achieve corporate profit (Effross, 1997, 954-958). The rise and rise of in-house counsel within corporations and the identification by Robert Nelson and Laura Beth Nielsen of the emergence of in-house counsel who play an 'entrepreneurial' function reveals the endpoint of this process. Nelson and Nielsen identified that in-house counsel are increasingly becoming integrated into the strategic decision-making of corporations. No-longer playing the role of just advising of rights and obligations, these in-house counsel have become included in the executive group, effectively becoming part of the controlling mind and will of the corporation (Nelson and Nielsen 2000). In science fiction, were there is a general absence of the legal professional but continual representation of the large corporation, there is a representation, at least in the cultural imagination, between big business and law.

In the UK context, the blurring divisions between large law firms and big business have recently become more apparent with changes brought about by the Legal Services Act 2007. Part five of the new Act ushered in "Alternative Business Structures” and a new period of deregulation for the legal profession. On a practical level, Alternative Business Structures 
allow non-legal firms to have equity in legal practices. Although this would theoretically allow for the streamlining of industries such as financial products and conveyancing the first companies to be granted licence for an Alternative Business Structure are the supermarket chain "The Co-operative" and haulage firm "Eddie Stobart". John Flood notes a number of advantages in the deregulation of the legal profession to consumers; ranging from choice, potentially cheaper and more accessible legal services, and integration with non-legal professional to provide “one-stop shopping for related services” (Flood, 2012, p. 545). Flood also details the potential advantages for legal service providers of Alternative Business Structures; such as increased access to equity, spreading and limiting risk, reducing overheads through merges with related entities such as insurance companies or real estate agencies, and enhancing employee satisfaction by allowing legal and non-legal career trajectories (Flood, 2012, p. 546).

While Flood makes a compelling audit of the external and internal market pressures leading to Alternative Business Structures, their coming into being draws greater attention to the inadequacies of self-regulation and it is yet to be seen how effective a regulator the newly established UK Legal Services Board will be. Writing before the introduction of Alternative Business Structures Francis noted:

The difficulties that the Law Society faces are most acute when we consider the elite sectors of the profession, the City firms operating in a global marketplace in a genuinely multi-disciplinary manner....These elite law firms work across disciplinary boundaries in a way that undermines claims to homogeneous legal knowledge for the entire profession. ... The nature of their work too, in corporate finance and banking, involves the cognitive bases of other professions.(Francis, 2004, p. 327-8)

Alternative Business Structures appear as the next step in the evolution of the corporatised legal profession exacerbating the shift away from professional ethics towards a profit-driven model., Evidence of this evolution can be seen more widely. Large Law firms (firms with 81 
or more partners), in the UK in 2008-2009 were responsible for the training of $34.9 \%$ of junior lawyers (Cole, et al., 2010, p. 40). Firms with 26-80 partners were responsible for the training of a further $20.4 \%$. In contrast sole practitioners were responsible for the training of only 5.3\% (Cole, et al., 2010, p. 40). This data suggests that the majority of the next generation of lawyers would have had their first experience of legal practice within large and potentially depersonalised corporate environments.

Oryx and Crake, Neuromancer and Gold Coast in their harsh visions of law and lawyers subsumed to the mega-corporation can be seen as realising the anxieties surrounding the not-so-slow movement towards the corporatisation of law. As the demarcation between the legal profession and big business becomes more difficult to determine the end result is, at least culturally, an inability to distinguish between lawyers and corporations. Science fiction plays out these concerns and questions the implications for any meaningful account of justice.

\section{Desire for a Lawyer-Hero}

In the previous two sections the absence of lawyers within science fiction was shown to reflect wider popular anxieties about the legal profession and the projection of those anxieties into the future. It reveals a highly negative set of connections and connotations concerning lawyers. Speculation of a future without lawyers, where access to justice was immanent, revealed a popular perception of lawyers as an obstacle to justice. Speculation of a future where lawyers have become indistinguishable from corporate interests projects the current trends concerning the corporatisation of legal practice were lawyers have become tools for the securing of profit for global capital. There is little that is redeeming for lawyers in these futures. 
However, the absence of lawyers in science fiction can be used to tell a rehabilitatory story of future lawyers. This begins with a closer re-examination of Judge Dredd. Dredd does project a simple fantasy of immediate justice. He's a nerd's dream, the über-bully who beats up the bullies (Barker, 1997). However, the series, as much as it has the macho-satisfaction of Dredd besting the baddies, shows the hollowness of the very system that it seemingly champions. In the recent Dredd film four corrupt judges are called upon by the drug lord nemesis to take Dredd out and the earlier 1995 film Judge Dredd was based around a realisation that the system was not infallible. Indeed, the Judge Dredd comic arc 'Origins' (Wagner, Equerra \& Walker 2007) which explores the creation of this legal system shows it compromised from the very beginning by lies and less than good intentions. Further Dredd's legal system simply does not work. For all the visible policing, judging and executing that Dredd and his fellow judges do, violence, drugs and vice is endemic. There is always another muscle-bound scumbag for Dredd rough-up in the next instalment, or more tellingly a corrupt Judge (including Dredd's own cloned brother) to take down. ${ }^{\mathrm{x}}$

What Dredd actually shows is the need for lawyers; for standards, processes and checks and balances. Dredd is actually less a "fascist fantasy” (Barker, 1997) and more a desire for a liberal constitution of rights, rule of law and the separation of powers. In creating this desire it also creates a desire for lawyers to work this machinery of justice. In showing an absence of lawyers in a less-than-justice system, the Dredd-universe actually highlights the need for lawyers to play the role of the lawyer-hero working the machinery of justice to ensure individual rights.

This is the third narrative about lawyers that arises from the absence of lawyers within science fiction. For although lawyers are rare science fiction's speculation of human 
futures is rarely utopian. Indeed, most science fictions are set within futures that seem harsh and unjust and even when there is the initial presentation of a utopia the narrative generally goes on to reveal that this ideal society is compromised, built on a lie.

An example of this is the recent science fiction blockbuster by Hugh Howey; Wool (2013). The premise is the familiar science fiction context of a post apocalypse humanity surviving in an underground silo centuries after a holocaust. The silo is comprised of a selfsufficient community featuring mechanics, IT specialists, farmers as well as political and policing systems evidenced by the offices of “mayor” and 'sheriff.” Justice in this community is simultaneously intrinsic and absent. In this community, all members are aware of the law. Lawyers, it could be supposed, are unnecessary due to the familiarity of the citizens with legal process. It could equally be argued, however, that justice is absent. All but two of the inhabitants of the silo are labouring under the pretence that there are no other survivors. Similarly, due to the withholding of information, most of the citizens of the silo are unaware of existence ever occurring outside of the silo.

The lack of lawyers in this context, rather than been seen as an inevitable consequence of current social mistrust could perhaps be envisaged as respectful. Lawyers, in the world of Wool were purposely left out of the silo. Lawyers ask too many questions, are innovators and can inspire social revolution. In this future lawyers could be seen as freedom fighters, standing up for the rights of individuals and so are written out; both in the text but also the world that the text is set in. In many ways the novel has resonances with Shakespeare’s much misquoted “The first thing we do let’s kill all the lawyers” from Henry VI (Part 2). Lawyers in Shakespeare's world are seen as a check on tyranny and killing them 
will allow Dick the Butcher to take $\backslash$ the throne. In Wool the uprising has already taken place and all the lawyers are dead.

The desire for the lawyer-hero to champion individual rights within a dystopian future has been occasionally substantiated by science fiction. In the little appreciated Gladiators-atLaw by Frederik Pohl and CM Kornbluth (1955/1964) a lawyer is present in the text, not as a custodian of the dark side of humanity or as a minion of hyper-capitalism, but rather as central protagonists valiantly righting the wrongs of the world. Gladiators-at-Law can be seen as a template for the worlds projected by later dystopian novels such as Oryx and Crake and Neuromancer. In it Pohl and Kornbluth present a divisive society of the haves who work for corporations and live in the highly controlled safety of the "plastic houses" and the havenots underemployed, scraping out a violent existence in the decaying post-war suburbs. Into this landscape of corporate dominance and social decay the character of "Charles Mundin, LL.B., John Marshall Law School” looms large (Pohl and Kornbluth, 1955/1964, p. 5). Through contacts within the corporations and within the lawless zone, knowledge of corporate law and a sophisticated understanding of human nature Mundin not only wins the day for his clients, two disenfranchised heirs to a corporate fortune, but engineers a stock market crash leaving the possibility of a new economic, if not social order (Tranter 2002). Mundin embodies the sort of lawyer-hero that the world of Dredd or Wool can be seen to desire.

Written in 1955 it could be suggested that Gladiators-at-Law is a dated text. Its representation of a lawyer-hero reflects the esteem that lawyers enjoyed before the turn in public opinion against lawyers that Asimow (2001) documents. However, there are some 
more recent science fiction lawyers that seem can be seen as embody the desire for the lawyer-hero generated by dystopian futures. The reimagined Battlestar Galactica (20032010) has a recurring minor character in the final two seasons of a lawyer Romo Lampkin (Mark Sheppard). At one level Lampkin is susceptible to Joseph’s criticism of science fiction lawyers as "Perry Masons in Space” (Joseph, 1995). However, Lampkin does not achieve an unlikely acquittal in a political show trial through legal knowledge or, in his kleptomaniac tendencies, a high moral character (Kapica, 2012). Rather, like Mundin he wins the day through judging characters and manipulating rules and social relations. In this Lampkin is an interesting embodiment of the lawyer-hero suggested by science fiction. That in imperfect worlds and futures, law and justice will require lawyers who are well versed in the dark side of humanity - who know and can manipulate people and rules - but do so not as agents for a totalising governmental or corporate power. Rather this possibly grubby and compromised, law work is dedicated to resisting totalising powers in the cause of individual rights and freedoms. This does present a problematic vision of the lawyer-hero, of ends justifying means and also a romantic desire for some knowable virtue - rights or freedom - to sanctify the lawyer's actions (Manderson, 2012). While we offer no resolution to this "dilemma of modernism" what we do suggest is that the few texts where characters like Mundin or Lampkin embody the desire for a lawyer-hero that is implicit in many science fictions, offer a precious resource through which to think not only the future of the legal profession, but the future of lawyering, in ways that does not have lawyers becoming extinct or subsumed to hyper-capitalism.

\section{Conclusion}

In this paper we have interrogated the absence of the lawyer in science fiction. In contrast to the argument presented by Joseph that the absence of the lawyer in science fiction shows a fault with science fiction's imagination, we suggest that the absence is meaningful; that the 
absence reflects current anxieties about lawyers. We then provided three interrogations of the absence of lawyers in science fiction. The first was that law and justice is represented as imminent; that law and justice will be manifest in the future without the need for lawyers. The second was that law and justice become corporatised; transformed into commodities that are owned and traded by an imagined hyper-capitalism. The third was the telling absence of lawyers and a projecting the need for the lawyer-hero in the future.

\section{Bibliography}

2012, (2009) Directed by Emmerich, R. (USA: Columbia Pictures).

Akira, (1988) Directed by Otomo, K. (Japan: TMS Entertainment).

Anon (2013) All-Time Box Office: USA, Internet Movie Database. Available at: http://www.imdb.com/boxoffice/alltimegross, accessed 2/14.

Aristodemou, M. (2000) Law and Literature; Journeys From Her to Eternity (Oxford, Oxford University Press).

Asimov, I. (1960) The Naked Sun (London, Grafton).

Asimov, I. (1964/1967) The Rest of the Robots (London, Panther).

Asimov, I. (1976) The Bicentennial Man (New York, Ballantine Books).

Asimov, I. (1981) Introduction: The First Century of Science Fiction in I. Asimow (Ed) Isaac Asimov Presents: The Best Science Fiction of the Nineteenth Century (New York, Knightsbridge) pp. 9-12.

Asimov, I. (1954/1983) The Caves of Steel (New York, Ballantine).

Asimov, I. (1985) The Robots of Dawn (London, Panther Books).

Asimov, I. (1950/2008) I, Robot (New York, Bantman).

Asimow, M. (1995) When Lawyers Were Heroes, University of San Francisco Law Review, Vol. 30, pp. 1131-1142.

Asimow, M. (1999) Bad Lawyers in the Movies, Nova Law Review, Vol. 24, pp.533-591. 
Asimow, M. (2001) Embodiment of Evil: Law firms in the Movies, University of Central Las Angeles Law Review, Vol. 48, pp.1339-1392.

Atwood, M. (2004) Oryx and Crake (St Ives, Virgo press).

Avatar, (2009) Directed by Cameron, J. (USA: Twentieth Century Fox).

Baksi, C. (2012) LASPO goes on the statute book, The Law Gazette. Available at: http://www.lawgazette.co.uk/news/laspo-goes-statute-book, accessed 2/14.

Barker, M. (1997) Taking the Extreme Case: Understanding a Fascist Fan of Judge Dredd in

D. Cartmell, I. Hunter, H. Kaye and I. Whelehan (Eds) Trash: Popular Culture and its Audiences (London, Pluto) pp. 14-30.

Baron, P. (2011) The Emperor's New Clothes: From Atticus Finch to Denny Crane in R. Mortensen, F. Bartlett and K. Tranter (Eds) Alternative Perspectives on Lawyers and Legal Ethics: Reimagining the Profession_London, Routledge) pp. 85-107.

Battlestar Galactica, (2004-2009) Directed by Various (USA: NBC Universal Television [2004-2007]) and (Universal Media Studios (UMS) [2007-2009])

Beard, A. (2010) From Hero to Villain: The Corresponding Evolutions of Model Ethical Codes and the Portrayal of Lawyers in Film, New York Law School Law Review, Vol. 55, pp. 962-978.

Bicentennial Man, (1999) Directed by Columbus, C. (USA: 1492 Pictures).

Blade Runner, (1982), Directed by Scott, R. (USA: Warner Brothers Pictures).

Boon, A. (2010) Professionalism under the Legal Services Act 2007, The International Journal of the Legal Profession, Vol. 17, pp. 195-232.

Boon, A. and Levin, J. (1999) The Ethics and Conduct of Lawyers in England and Wales (Oxford, Hart Publishing).

Cole, B. Fletcher, N. Chittenden, T. and Cox, J. (2010) Trends in the solicitors' profession: Annual Statistical Report 2009, (London, The Law Society)

Corcos, C. Corcos, I and Stockhoff, B. (1999) Double-Take: A Second Look at Cloning, Science Fiction and Law, Louisiana Law Review, Vol. 59, No. 4, pp. 1041-1099.

District 9, (2009) Directed by Blomkamp, N. (USA: TriStar Pictures).

Dredd, (2012) Directed by Travis, P. (USA: DNA Films). 
Effross, W. (1997) High-Tech Heroes, Virtual Villains, and Jacked-In Justice: Visions of Law and Lawyers in Cyberpunk Science Fiction, Buffalo Law Review, Vol. 45, pp. 931-974. Flood, J. (2012) Will There Be Fallout from Clementi? The Global Repercussions for the Legal Profession after the UK Legal Services Act 2007, Michigan State Law Review, Vol. 2012, pp. 537-542.

Flood, J. (2013) Response to the Bar Council and Bar Standards Board Responses to the Flood-Hviid Report on the Cab Rank Rule for the Legal Services Board, SSRN, Available at http://papers.ssrn.com/sol3/papers.cfm?abstract_id=2258707, accessed 2/14.

Francis, A. M. (2004) Out of touch and out of time: lawyers, their leaders and collective mobility within the legal profession, Legal Studies, Vol. 24. No. 3, pp. 322-348.

Francis, A. M. (2011) At the Edge of Law; Emergent and Divergent Models of Legal Professionalism (Surrey, Ashgate).

Futurama, (1999-2011) Directed by Various (USA: Twentieth Century Fox).

Galanter, M. and Roberts, S. (2008) From Kinship to Magic Circle: The London Commercial Law Firm in the Twentieth Century, International Journal of the Legal Profession, Vol. 15, pp.143-178.

Gattaca, (1997) Directed by Niccol, A. (USA: Columbia Pictures).

Gibson, W (2004) Neuromancer: 20th Anniversary Edition (New York, Ace Books).

Howey, H. (2013) Wool (London, Arrow Books).

I-Robot, (2004), Directed by Proyas, A. (USA: Twentieth Century Fox).

Joseph, P. R. (1998) Science Fiction in R. M. Jarvis and P. R. Joseph (Eds) Prime Time Law: Fictional Television as Legal Narrative (Durham, Carolina Academic Press) pp. 155-166.

Joseph, P. R. and Carton, S. (1992) The Law of the Federation: Images of Law, Lawyers and the Legal System in Star Trek: The Next Generation, University of Toledo Law Review Vol. 24, No. 1, pp. 43-97.

Joseph, P. R. and Carton, S. (1995) Perry Mason in Space: A Call for More Inventive Lawyers in Television Science Fiction Series in M. T. Wolff and D. F. Mallett (Eds) Imaginative Futures: Proceedings of the 1993 Science Fiction Research Association Conference (San Bernardino, Science Fiction Research Association Press) pp. 307-316. Judge Dredd, (1995) Directed by Cannon, D. (USA: Hollywood Pictures)

Kapica, S. S. (2012) "What a Glorious Moment in Jurisprudence”: Rhetoric, Law, and Battlestar Galactica, Law, Culture and the Humanities, DOI: 101.1177/1743872112466720.

Legal Services Board (2012) About Us, Legal Services Board. Available at: http://www.legalservicesboard.org.uk/about_us/index.htm accessed 2/14. 
Legal Services Consumer Panel (2013) YouGov Survey Results, Legal Services Consumer Panel. Available

at:

www.legalservicesconsumerpanel.org.uk/ourwork/CWI/documents/Tracker\%20Survey\%202 013\%20recent\%20users.xlsx, accessed 2/14.

Leslie-McCarthy, S. (2007) Asimov's Posthuman Pharisees: The Letter of the Law Verses the Spirit of the Law in Isaac Asimov's Robot Novels, Law, Culture and the Humanities, Vol. 3, No. 3, pp. 398-415.

Looper, (2012) Directed by Johnson, R. (USA: Endgame Entertainment).

Manderson, D. (2012) Kangaroo Courts and the Rule of Law: The Legacy of Modernism (London,Routledge).

Mills, P. (1977) The Return of Rico, 2000 AD Vol. 30 (17 September).

Minority Report, (2002) Directed by Spielberg, S. (USA: Twentieth Century Fox).

Moon, (2009) Directed by Jones, D. (USA: Sony).

Morgan Poll. (2013) Image of Professional Survey 2013, Morgan Poll, Available at:

http://www.roymorgan.com/ /media/Files/Findings\%20PDF/2013/May/4888-Image-ofProfessions-2013-April-2013.pdf accessed 2/14.

Nelsen, R. \& Nielsen, L. (2000), Cops, Counsel, and Entrepreneurs: Constructing the Role of Inside Counsel in Large Corporations, Law and Society Review Vol. 34, No. 2, pp. 457-494.

Newport, F. (2012) Congress Retains Low Honesty Rating, Gallup Poll, Available at: http://www.gallup.com/poll/159035/congress-retains-low-honesty-rating.aspx, accessed 2/14.

Nicolson, D. \& Webb, J. (1999) Professional Legal Ethics: Critical Interrogations (Oxford, Oxford University Press).

Parker, M. (1998) Judgement Day: Cyborganization, Humanism and Postmodern Ethics, Organization, Vol. 5, No. 4, pp. 503-518.

Peters, T. D. (2008) Allusions to Theology: I, Robot, Universalism and the Limits of Law, Media and Arts Law Review, Vol. 13, pp. 77-92.

Peters, T. D. (2012) "The Force" as Law: Mythology, Ideology and Order in George Lucas's Star Wars, Australian Feminist Law Journal, Vol. 36, pp. 125-143.

Pohl, F. and Kornbluth, C. M. (1955/1964) Gladiator-at-Law (London, Pan Book).

Robson, P. and Silbey, J. (2012) Introduction in P. Robson and J. Silbey (Eds) Law and Justice on the Small Screen (Oxford, Hart Publishing) pp. 1-12. 
Sanderson, J. (2013) Pigoons, Rakunks and Crakers: Margaret Attwoods Oryx and Crake and Genetically Engineered Animals in a (Latourian) Hybrid World, Law and Humanities, Vol. 7, No. 2, pp. 218-239.

Schedle, P. (1993) Androids, Humanoids, and Other Science Fiction Monsters (New York, New York University Press).

Sechooler, A. (2008) Globalization, Inequality and the Legal Services Industry, International Journal of the Legal Profession, Vol. 15, pp.231-248.

Sharp, C. (2012) 'Riddle Me This...?’ Would the World Need Superheroes if the Law could Deliver 'Justice’? Law Text Culture, Vol. 16, pp. 353-378.

Shepherd, J. (2009) Money, Politics and Impartial Justice, Duke Law Journal, Vol. 58, p. 623-685.

Sherwin, R. K. (2000) When Law Goes Pop (London, University of Chicago Press).

Solicitors Regulation Authority (2011) Code of Conduct for England and Wales, Solicitors Regulation Authority, Available at: http://www.sra.org.uk/solicitors/handbook/welcome.page accessed 2/14.

Species, (1996) Directed by Donaldson, R. (USA: Metro-Goldwyn-Mayer).

Splice, (2009) Directed by Natali, V. (USA: Gaumont).

Stanley Robinson, K. (1988/1995) Gold Coast (New York, Orb Books).

Star Trek, (1966-1969) Directed by Various (United States of America, Paramount Television).

Star Trek: The Next Generation, (1987-1994) Directed by Various (United States of America, Paramount Television).

Star Wars Episode II: Attack of the Clones, (2002) Lucas, G. (United States of America, Twentieth Century Fox).

The American Bar Association (2013) Model Rules of Professional Conduct, The American Bar Association, Available at: http://www.americanbar.org/groups/professional_responsibility/publications/model_rules_of _professional_conduct/model_rules_of_professional_conduct_table_of_contents.html, accessed 2/14. 
The Bar Standards Board (2013) Code of Conduct, The Bar Standards Board, Available at: https://www.barstandardsboard.org.uk/regulatory-requirements/the-code-of-conduct/, accessed 2/14.

The Day the Earth Stood Still, (1951) Directed by Wise, R. (USA: Twentieth Century Fox).

The Day After Tomorrow, (2004) Directed by Emmerich, R. (USA: 20 ${ }^{\text {th }}$ Century Fox).

The Devil’s Advocate, (1997) Directed by Hackford, T. (USA: Warner Bros).

To Kill a Mockingbird, (1962) Directed by Mulligan, R. (USA: Universal International Pictures).

Tranter, K. (2002) Terror in the Texts: Technology - Law - Future, Law and Critique, Vol. 13, No.1, pp. 75-99.

Tranter, K. (forthcoming). I, Archive: Digital Legality and SyFy’s Caprica in W. P. MacNeil, T. D. Peters and K. Crawley (Eds) Don't Blink: Life and Death in Cultural Legal Studies, Routledge.

Tranter, K. (2011) The Speculative Jurisdiction; The Science Fictionality of Law and Technology, Griffith Law Review, Vol. 20, pp.817-850.

Travis, M. (2011) Making Space; Law and Science Fiction, Law and Literature, Vol. 23, pp. 241-261.

Ury, F. S. (2011) Atticus Finch and the Future of the Legal Profession, Southernwestern Journal of International Law, Vol. 18, No. 1, pp. 225-232.

Wagner, J. (1978) The Face Change Crimes 2000 AD, Vol. 52 (28 February).

Wagner, J. Equerra, C. \& Walker, K. (2007) Judge Dredd; Origins (London, Rebellion).

YouGov (2013) Consumers less satisfied with legal services, YouGov, Available at: http://yougov.co.uk/news/2013/04/12/consumers-less-satisfied-legal-services/, accessed 2/14.

\footnotetext{
${ }^{\mathrm{i}}$ Hyper-Chicken was introduced in Lynch, J. and P. Cooke (1999). Brannigan, Begin Again. Futurama. M. Groening and D. X. Cohen. United States, Fox. On Atticus Finch as a popular cultural representative of the lawyer ideal see Baron, P. (2011). The Emperor's New Clothes: From Atticus Finch to Denny Crane. Alternative Perspectives on Lawyers and Legal Ethics: Reimagining the Profession R. Mortensen, F. Bartlett and K.
} 
Tranter. London, Routledge: 85-107, Ury, F. S. (2011). "Atticus Finch and the Future of the Legal Profession." Southernwestern Journal of International Law 18(1): 225-232.

ii http://www.gallup.com/poll/159035/congress-retains-low-honesty-rating.aspx (Last accessed 24/7/13)

iii Available at www.legalservicesconsumerpanel.org.uk/ourwork/CWI/documents/Tracker\%20Survey\%202013\%20recent\%20 users.xlsx (last accessed 5/8/13)

iv Morgan Poll (2013) "Image of Professional Survey 2013"

http://www.roymorgan.com/ /media/Files/Findings\%20PDF/2013/May/4888-Image-of-Professions-2013-April2013.pdf accessed 20 February 2014. Over the 28 years that the Morgan Poll has been undertaken lawyers have on average be seen by only $33.8 \%$ of respondents as ethical and honest.

v See for example The Devil's Advocate (1999), The Change-Up (2011), Suits (2011-2013).

${ }^{v i}$ http://www.thisismoney.co.uk/money/article-2269520/Best-paid-jobs-2012-Official-figures-national-averageUK-salaries-400-occupations.html, http://www.thelawyer.com/newly-qualifieds-remain-at-top-of-pay-scaledespite-wage-freezes/1001351.article

vii “The ABA believed that the Canons - and later the Model Code - needed significant revision and updating because of the dramatic changes that the legal profession underwent in the second half of the twentieth century.... First, the number of practitioners increased substantially. In 1960, there were 286,000 people employed in the legal profession in the United States. By 1999, the profession employed 946,000 people. Second, salaries rose exponentially during that time. In 1953, lawyers starting at large, prominent firms could expect to make \$40oo per year; in 1994, starting salaries at large law firms could top \$70,000 per year, and reached almost $\$ 100,000$ by the end of the decade.” (Beard 2010:971)

viii In the context of US judicial elections for example see J. Shepherd (2009) Money, Politics, and Impartial Justice, Duke Law Journal, Vol. 58, p. 623.

${ }^{\text {ix }}$ http://www.lawgazette.co.uk/news/laspo-goes-statute-book

x Dredd's corrupt brother Rico was first introduced in Mills, P. (1977). "The Return of Rico." 2000 AD 30(17 September). He is also used as the main villain in the 1995 film. 